\title{
CITRA POLITIK PRABOWO-SANDI DALAM PEMILIHAN PRESIDEN (PILPRES) 2019 DI AKUN MEDIA SOSIAL INSTAGRAM
}

\author{
Muttaqin, Putri Maulina, Said Fadhlain \\ putrimaulina@utu.ac.id \\ Program Studi Ilmu Komunikasi, Universitas Teuku Umar
}

\begin{tabular}{ll} 
Article Info & \\
\hline $\begin{array}{l}\text { Keyword: } \\
\text { Political Branding, }\end{array}$ & $\begin{array}{l}\text { Personal } \\
\text { branding, } \\
\text { formation,Instagram }\end{array}$
\end{tabular}

\begin{abstract}
Prabowo Subianto and Sandiaga Uno are one of the candidate pairs as Presidential and Vice President Election candidates in the 2019 Presidential Election. In this event, there was many strategies used by the candidates to attracting public electability. The aims of this study is to determine the image of Prabowo-Sandi's in the political branding process that showed in instagram@indonesiaadilmakmur.This study used the Semiotic Analysis approach to look the meaning of political image which represented in instagram @indonesiaadilmakmur and the Political Branding concept that focused in three indicators: Appearance, Personality and Political Key Message. The method used in this study is semiotic analysis by Charles Peirce with a qualitative approach in interpretive paradigm. Finally, th results of this study found that the process of Prabowo-Sandi's branding formed through three indicators political branding such Appearance, Personality, and Political Key Message in generally are depicted as personal figure of religious, assertive, hard, patriot, polite, calm, integrity, smart and close to society.
\end{abstract}

Copyright (C) 2020 Interaksi: Jurnal Ilmu Komunikasi. All rights reserved.

\section{PENDAHULUAN}

Indonesia kembali mengalami perhelatan akbar yaitu Pemilihan Presiden pada tanggal 17 April 2019. Pemilihan Presiden (Pilpres) lahir dari salah satu bagian proses sekaligus hasil dari sebuah sistem demokrasi. Banyak hal maupun fenomena yang tercipta mulai dari ketatnya persaingan, isu antar paslon (pasangan calon), hingga citra yang dibangun sebagai strategi pemenangan.

Untuk mendapatkan dukungan dari mansyarakat, pada sebuah kompetisi politik mengharuskan seluruh relawan bekerja keras. Salah satu strategi politik yang dapat digunakan adalah melakukan iklan politik melalui media. Saat inimedia massa sering dimanfaatkan sebagai sarana pencitraan dengan mengusung iklaniklan yang bertemakan politik. Iklan politik bertujuan menyampaikan citra guna menguatkan positioning. Konsep positioning dalam iklan merupakan suatu proses kesan yang dibentuk untuk kemudian diubah. Sehingga menjadi alternatif bagi konstituen guna me- menangkan suara.

Dalam hal ini, penggunaan Political Branding merupakan salah satu cara strategis untuk membangun citra politik. Dimana strategi ini menjadi salah satu contoh dari branding yang dilakukan Barrack Obama dalam Pemilu Presidensial Amerika Serikat Tahun 2008. Pada saat itu, untuk menguatkan brandingyang telah dibangun dari dunia nyata, kemudian disempurnakan kembali dengan branding yang dibangun ke dunia maya menggunakan media digital baru seperti melalui Facebook, Twitter, YouTube, MySpace dan lain sebagainya.

Kepercayaan publik dan citra positif kontestan sesungguhnya dapat dicapai dengan mengonstruksikan identitas dirinya, menawarkan produk politik yang menarik, serta menancapkan positioning yang kuat dalam benak konstituen. Dengan menciptakan branding kuat dan jelas, maka kesan terhadap seorang kandidat calon politik akan tertanam kokoh secara langsung dalam benak hati masyarakat. 
Hal ini juga ditunjukkan oleh kontestan yang berlaga di Pemilu Pilpres 2019 yang diikuti oleh dua pasangan calon Presiden dan Wakil presiden yaitu Joko Widodo-Ma'ruf Amin dan Prabowo Subianto-Sandiaga Salahuddin Uno. Kedua kandidat saling menjalankan kampanye politik dengan menampilkan branding guna meraih elektabilitas tinggi dibanding lawannya. Berdasarkan kutipan yang dilansir dari Tempo.co pada edisi tanggal 17 Januari 2018telah dijelaskan bahwa hasil elektabilitas kedua kandidat cenderung mandek dan berbeda.

Melalui survei yang dilakukan Indonesia Development Monitoring (IDM) yang pada tanggal 24 Mei 2018, menunjukkan bahwa elektabilitas Prabowo sebesar 50,1\%, dan elektabilitas Jokowi mencapai 29,8\%. Pencapaian tersebut menempatkan Prabowo sementara dengan tingkat elektabilitas tertinggi dibandingkan pesaingnya.Sedangkan pada survei yang dilakukan Charta Politika tanggal 22 Desember 2018 hingga tanggal 02 Januari 2019. Hasilnya tercatat elektabilitas JokowiMa'ruf 53,2 persen dan Prabowo-Sandi 34,1 persen.

Sesuai dengan data survei elektabilitas kedua kandidat diatas, hal ini menunjukkan bahwa PrabowoSandi sebagai kubu pesaing petahana dipandang menarik ditelaah lebih lanjut terutama pada sisi pembentukan strategi Political Branding. Untuk itu, kajian ini bertujuanmelihat bagaimana citra politik PrabowoSandi dalam Pemilihan Presiden (Pilpres) 2019 dibentuk oleh relawan di akun media sosial Instagram. Kajian tentang Political Brandinginimenekankan pada konteks strategi branding politik yang perlu dibentuk untuk dapat memberikan pengaruh pada khalayak tentang subjek politik. Dalam komunikasi politik, brandingpolitik diperlukan sebagai bentuk keefektifan komunikasi.

Konsep tentang Political Branding ini merujuk pada kajian penelitian yang dilakukan oleh Lidya Joyce Sandra tentang "Political Branding Jokowi Selama Masa Kampanye Pemilu Gubernur DKI Jakarta 2012 di Media Sosial Twitter". Pada penelitian ini menyimpulkan strategi branding politik Jokowi yang dibentuk di Twitter yaitu penampilan, personalitas, dan pesanpesan politis. Dari penjabaran ketiga konsep tersebut dapat diambil kesimpulan bahwa sosok Jokowi yang memiliki perbedaan dengan kandidat lainnya seperti merakyat, terbuka, dan disukai masyarakat. Sehingga branding politik yang digunakannya berhasil dan membuat sosok Jokowi mudah dikenali dan disenangi masyarakat sebagai calon pemimpin di DKI Jakarta 2012. Dari hasil temuan pada penelitian ini bahwa Political Branding tidak hanya berorientasi pada penampilan dan kepribadian saja, melainkan pentingnya membangun hubungan dengan masyarakat melalui pesanpesan kunci politik.Hal itu seperti adanya pemberian harapan, dukungan publik dan laporan setiap agenda aktivitas yang dilakukannya. Ditambah, penampilan yang melekat pada dirinya merefleksi ulang keseluruhan pesan politik dari pemaknaan pakaian yang dikenakan (Sandra, 2013).

Kemudian penelitian tentang Political Branding juga merujuk pada hasil kajian Asmaul Husna tentang "Analisis Political Branding Calon Kepala Daerah dalam Kampanye Pilkada Aceh 2017". Penelitian ini menggambarkan bagaimana pengaruh perbedaan latar belakang sosial yang dimiliki oleh kontestan politik sebagai mantan kombatan dan non-kombatan dalam membentuk Political Branding pada kampanye Pilkada Aceh tahun 2017 silam. Proses branding yang timbul dari kedua faktor tersebut dipengaruhi oleh identitas kombatan dan non-kombatan yang dijadikan subjek untuk diperjual belikan selama masa kampanye. Lebih spesifik, kontruksi Political Branding diciptakan dengan menyebarluaskan segala hubungan atas informasi-informasi dan terdokumentasi ke dalam berbagai media kampanye resmi yang digunakan oleh para kandidat calon politik (Husna, 2017).

Selain itu, penelitian tersebut menitikberatkan pada kedua kontestan yang memiliki latar belakang sosial yang berbeda sebagai calon kepala daerah provinsi Aceh.Sehingga branding yang dihasilkan bertujuan untuk menguatkan kesan kontestan tersebut. Hasilnya, bahwa label latar belakang sosial yang dimiliki oleh kontestan sebagai mantan kombatan dan non-kombatan ternyata mampu mempengaruhi perbedaan dalam nuansa kajian Political Branding yang mereka munculkan sehingga dapat menarik simpati masyarakat pada masa kampanye Pilkada Aceh tahun itu.

Sholihul Abidin dalam penelitiannya tentang 
"Political Branding Ridwan Kamil Pada Masa Kampanye Pilgub Jawa Barat 2018 Melalui Twitter" menekankan perspektif yang berbeda tentang konsep Political Branding ini, yaitu merujuk pada parameter aspek-aspek di dalam Political Branding itu sendiri. Sebagai subjek politik, strategi Ridwan Kamil dalam memenangkan Pilkada Jawa Barat tahun 2018, tidak lepas dari penggunaan konsep Political Branding yang terdiri dari penampilan, personalitas, maupun pesan kunci politik. Strategi kampanye yang berbeda dilakukan bukan hanya menggunakan model face to face communication atau komunikasi tatap muka. Melainkan seleksi terhadap penggunaan media kampanye yang dipilih. Hal itu, semakin didukung oleh keaktifannya di media sosial seperti Twitter, Facebook dan Instagram. Selain itu, terdapat aspek lain yang secara tidak langsung ikut terlibat dalam membentuk citra politik dirinya yaitu seperti membangun hubungan baik dengan konstituen, orisinalitas seorang pemimpin, nilai -nilai personal yang disalurkan serta tanggap terhadap teknologi (Abidin, 2019).

Sebagaimana hasil dari penelitian ini menunjukkan strategi Political Branding yang dilakukan Ridwan Kamil menggambarkan bahwa dirinya sebagai sosok kandidat yang terbuka, dekat dengan masyarakat, kredibel dan merakyat (egaliter).Sehingga hal itu yang kemudian menciptakan suatu brand identity yang melekat pada diri Ridwan Kamil sebagai seorang pemimpin.

Penelitian terdahulu memiliki keterkaitan dengan judul pada penelitian kali ini yaitu mempunyai kesamaan dalam pengambilan tema tentang politik dimana masing-masing penelitian di atas bertema Pilkada dan Political Branding. Namun, penelitian ini tentang Pilpres dan citra politik yang dibentuk melalui konsep Political Branding dan dibedah seacara mendalam menggunakan teori semiotika segitiga makna. Selain itu, objek dan metode penelitian yang digunakan peneliti berbeda. Maka, fokus Penelitian ini akan lebih tertuju pada iklan politik sebagai citra Prabowo-Sandi yang dimunculkan melalui media sosial Instagram sehingga memunculkan sebuah trust yang melekat dibenak masyarakat. Peneliti juga mengadopsi teori penelitian terdahulu pada penelitian ini karena memiliki kedekatan sehingga dianggap relevan dengan ke- lanjutan penelitian kali ini.

\section{KAJIAN PUSTAKA}

Metodologi

Adapun metode kajian yang digunakan adalah analisis isi kualitatif, dengan menggunakan pisau bedah semiotika. Santoso (2013: 10) memberikan penjelasan bahwa semiotika merupakan ilmu yang mempelajari tanda-tanda dan berperan penting dalam menggungkapkan makna-makna yang terdapat di dalam sebuah teks. Bagi semiotika, pesan merupakan kontruksi tandatanda melalui interaksi antara pihak pengirim pesan atau penstransmisi pesan kepada media sampai penerima pesan sehingga adanya respon terhadap makna dari pesan tersebut. Dalam demikian, peneliti menggunakan Teori Semiotika Charles Sanders Pierce tentang Segitiga Makna (Triangle Meaning) sebagai unit analisis yang terdiri dari tiga elemen utama yang dikemukakan oleh C.S. Pierce dalam Eka Saputra (2019), yaitu;

1. Tanda (Sign), yaitu sesuatu yang berupa fisik yang rujukannya di luar tanda itu sendiri seperti menghadirkan beberapa tanda guna membangun citra positif bagi kontestan politik.

2. Objek (Object), yaitu perkara atau orang yang menjadi pokok pembicaraan yang dirujuk menjadi tanda. Misalnya, menjadikan ikon-ikon yang tampil di masyarakat menjadi kontruksi identitas terhadap dirinya.

3. Interpretasi (Interpretant), yaitu sebuah konsep pemikiran dari pengguna tanda sehingga memunculkan makna tertentu. Hal ini merupakan pengaplikasian dari ikon-ikon yang sebelumnya untuk dibawa ke dalam kehidupan sehari-harinya.

Tiga elemen tanda inilah yang menjadi unit analisis atau alat bedah peneliti dalam menginterpresentasikan secara mendalam tentang memahami Political Branding Prabowo-Sandi dalam media sosial Instagram yang diunggah akun@indonesiaadilmakmur, dengan mengaitkan sesuai konsep teoritis yang menggunakan data-data atau posting-an yang telah dikumpulkan sesuai dengan kebutuhan penelitian. 
Kajian Konseptual

\section{a. Political Branding}

Political Branding menurut Haroen seperti dikutip dari Fatmawati (2018: 62), menjelaskan bahwa branding merupakan suatu aktivitas yang dilakukan untuk membangun persepsi dan kepercayaan orang lain. Sehingga branding dibutuhkan oleh semua orang yang mempunyai kepentingan dalam mendapatkan sesuatu dari orang lain. Sedangkan menurut pemikiran Marshment dalam (Sandra, 2013: 4), mengatakan bahwa branding merupakan satu bentuk baru dalam pemasaran politik. Kata branding berasal dari kata bahasa Inggris, "brand" yang berarti merek. Namun, para semua pakar sepakat dalam merumuskan brand bukanlah sekedar logo atau simbol dari sebuah produk, melainkan representasi simbolis atas identitas dari sebuah komoditi pemasaran atau dapat diasumsikan sebagai kontestan politik. Mitsikopolou (2008: 112) menguraikan bahwa citra dan personalitas pemimpin dapat dibentuk oleh proses branding. Selain itu, branding bahkan dapat membantu mengubah kandidat dalam memelihara reputasi dan mendapatkan dukungan.

Berbeda dengan branding pada sebuah produk, Political Branding tidaklah bertujuan untuk menghasilkan keuntungan seperti laba. Akan tetapi, lebih kepada menanamkan kesan yang kuat seperti apa yang diinginkan oleh aktor politik. Misalnya, membangun ikatan secara emosional guna membentuk image positif. Selain itu, produk dalam Political Branding ini bukanlah berupa produk atau barang pada umumnya, tetapi berupa gagasan-gagasan, kebijakan maupun janji politik yang di tawarkan (Husna, 2017: 59 -60). Sehingga dapat disimpulkan bahwa Political Branding merupakan suatu cara strategis dan menjadi alternatif pilihan oleh consumer branding dalam membangun citra politik mereka.

Menurut Gelder (2003), menjabarkan bahwa variabel pembentuk branding terdiri dari positioning, personality, dan brand identity. Sedangkan menurut Sonnies (2011), pada dasarnya branding politisi dibentuk dari pemahaman masyarakat secara tidak objektif. Tidak hanya berupa faktor personal kandidat tetapi juga berupa dari penampilan seperti model rambut, pakaian, yang secara tidak langsung akan memberi dampak ter- hadap pembentukan citra kandidat politik (Mitsikopoulou, 2008:7).

Beranjak dari dua pemikiran tersebut maka peneliti merumuskan tiga indikator kunci yang relevan untuk digunakan sebagai landasan berpikir dalam memahami dan menginterpretasikan bagaimana Political Branding Prabowo-Sandi yang dibangun di media sosial Instagram.

1. Penampilan (appereance) dapat ditelaah dari segi pakaian, atribut kampanye, gestur tangan (handsign), gaya rambut maupun simbol-simbol yang dipakai dalam kampanye.

2. Personalitas (personalities) yaitu kepribadian personal branding kandidat yang dapat dicermati dari aktivitas kampanye seperti dengan mengamati; Pertama, gaya bicara yang terdiri dari tatanan bahasa, tingkah laku maupun bahasa tubuh yang ditampilkan kandidat. Kedua, hubungan yaitu kemampuan kandidat dalam bersosialisasi atau dekat dengan masyarakat. Ketiga, kemampuan persuasi yaitu karir masa lalu serta kemampuan intelektual kandidat dalam menyampaikan pidato kampanye guna membentuk suatu kesan (image) yang melekat ke dalam benak masyarakat.

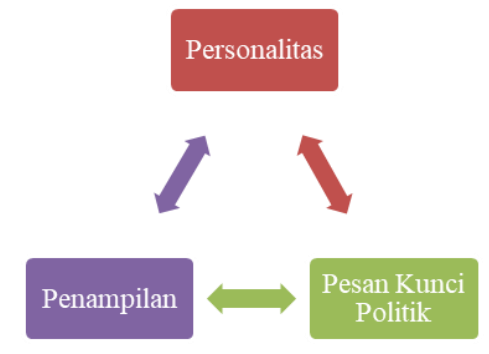

Sumber: Diolah dari Gelder (2003) dan Sonies

(2011)

3. Pesan kunci politik (political key message). Pada indikator ini adalah berupa janji politik, gagasan politik, aspirasi, harapan, nilai maupun ideologi politik. Berikut merupakan konsep Political Branding yang penulis rangkum untuk kemudian dikembangkan menjadi penggambaran representasi branding yang ditampilkan Prabowo-Sandi.

\section{TEMUAN DAN DISKUSI}

Setelah mengumpulkan data penelitian yang diperoleh dari unggahan salah satu akun resmi relawan Prabowo-Sandi bernama@indonesiaadilmakmur yang 
menjadi subjek penelitian ini. Dengan membatasi waktu periode selama enam bulan yaitu pada bulan Agustus 2018 sampai dengan Februari 2019 dengan pertimbangan tingkat intensitas masa kampanye politik berlangsung. Di sepanjang periode tersebut terdapat 754 posting-an. Dari jumlah posting-an tersebut kemudian peneliti mempersempit dan menjadikan subjek penelitian hanya 12 posting-an saja terdiri dari empat foto, empat caption foto dan empat video. Hal itu mengacu pada kebutuhan dan tingkat relevansi data terhadap objek kajian berlandaskan parameter konsep maupun teoritis.

Dengan demikian, peneliti menganalisis data menggunakan teori segitiga makna C.S. Pierce untuk menemukan representasi dari konsep Political Branding yang terdiri dari indikator; Penampilan (Appereance), Personalitas (Personalities), dan Pesan Kunci Politik (Political key message) pada Prabowo dan Sandi seperti uraian penjelasan berikut.

Personal branding Prabowo-Sandi Pada Sisi Penampilan

Merujuk istilah dari definisi Political Branding tentang konsep penampilan yang diolah dari Gelder (2003) dan Sonnies (2011), yaitu pada indikator ini dapat dilihat dari segi pakaiaan, atribut kampanye, gestur tangan (hand sign), gaya rambut, maupun simbolsimbol yang digunakan oleh kandidat. Dubrin (2006) menjelaskan, dalam proses komunikasi politik, salah satu poin utama yang diperlakukan agar dapat memengaruhi khalayak target politik adalah pada sisi penampilan personal (appearance). Penampilan dapat diartikan sebagai bentuk citra diri yang terpancar dari seorang individu.

Berdasarkan hasil analisis peneliti dengan menggunakan alat bedah semiotika segitiga makna (triangle meaning), peneliti melihat bahwa Prabowo sering menggunakan pakaian kemeja berwana cokelat dengan saku berjumlah empat serta peci hitam yang menutupi rambutnya. Maka oleh sebab itu, gaya pada pakaian Prabowo tergolong ke dalam trikotomi tanda (sign) yaitu qualisign. Qualisign sendiri adalah sesuatu yang dimiliki untuk menjadi dan berfungsi sebagai tanda. Misalnya, warna cokelat pada kemeja tersebut dikaitkan dengan alam yang merepresentasikan sifat organik, menyeluruh, sederhana dan jujur. Sedangkan peci hitam identik dengan simbol kepribadian religius dan nasionalis.

Adapun branding pakaian yang ditampilkan Prabowo merepresentasikan kembali gaya safari Soekarno. Dari sejarah dan pemaknaan personal Prabowo akan kemeja safari tersebut, apabila dikaitkan dengan konteks Indonesia mempunyai makna khusus di dalamnya. Dengan menggunakan pakaian gaya safari itu, Prabowo ingin menunjukkan identitas dirinya sebagai sosok pejuang yang memperjuangkan keadilan rakyat dan bangsa Indonesia. Dahlil selaku Koordinator Badan Pemenangan Nasional menjelaskan (BPN) bahwa penggunaan pakaian safari itu karena merupakan melambangkan simbol perjuangan yang digunakan oleh para pendiri bangsa terdahulu seperti Presiden dan Wakil Presiden Indonesia pertama yaitu SoekarnoHatta (Erdianto, 2018).

Hal itu, semakin memperkuat penelitian yang dilakukan oleh Amalo (2015, 168-169), bahwa Prabowo Subianto dicitrakan dengan sosok Soekarno atau dikenal dengan sebutan Soekarnoisme. Pencitraan tersebut dibentuk mirip dengan Bung Karno mulai dari penggunaan baju, peci hingga meminjam kharisma sosok Proklamator tersebut.Lebih spesifik, aksi meniru sosok Soekarno itu bukam saja pada bentukan fisik, tetapi juga simbolisme yang digunakan. Selain itu, dalam Fitri (2015: 104), mengatakan Prabowo secara tidak langsung ingin menjelaskan bahwa dirinya sangat berwibawa menggunakan pakaian rapi. Di dalam fotonya Prabowo juga terlihat selalu tersenyum seakan mencitrakan sebagai calon pemimpin yang ramah.

Akan tetapi, dibandingkan dengan kandidat lainnya, penggunaan pakaian safari kemeja coklat bersaku empat termasuk gaya pakaian yang jarang digunakan oleh politisi Indonesia. Kemudian gaya rambutnya yang mengenakan peci hitam seperti banyak dilakukan politisi lainnya yakni menunjukkan dirinya sebagai politisi yang religius dan nasionalis. Hal ini termasuk dalam trikotomi objek (object) yang semakin memperkuat politik identitas Prabowo-Sandi sebagai pasangan calon hasil Ijtima' Ulama.

Sedangkan gaya pakaian Sandiaga Uno juga berbeda dari Prabowo sehingga memiliki branding dan 
citra tersendiri. Selama masa kampanye, Sandi terlihat selalu mengenakan baju kaos yang berwarna biru. Penggunaan gaya pakaian Sandi demikian merupakan bagian dari fashion style. Yulia (2011) menjelaskan fashion merupakan sebagai ungkapan ekspresi diri dan komunikasi dari pemakainya dengan memberikan implikasi bagi orang lain tentang bagaimana orang mengkomunikasikan nilai-nilai, status, kepribadian, identitas, dan perasaan kepada orang lain. Karena fashion pada dasarnya mampu mengekpresikan sesuatu yang tidak dapat terucap secara verbal, maka fashion seringkali digunakan untuk menunjukkan identitas personal dari pemakainya. Hanya dengan mengenakan pakaian tertentu, orang lain akan dapat menilai kepribadian dan citra dirinya.

Adapun penggunaan baju atau kaos Sandi yang berwarna biru ini termasuk bagian dari trikotomi tanda qualisign yang jauh dari pakaian kelompok elit dimana semua lapisan masyarakat bisa menggunakan pakaian secara kasual di kehidupan sehari-hari mereka. Pemilihan warna biru ini juga seakan memunculkan maksud tertentu. Berdasarkan semiotika warna, biru bersifat universal dan dapat diinterpretasikan dengan sesuatu yang saling berhubungan. Dimana salah satunya dimaknai sebagai warna langit dan laut yang memiiki arti ketenangan. Dengan mengenakan pakaian tersebut, Sandi mengharapkan perpolitikan di Indonesia mempunyai esensi tenang, sejuk dan damai. Selain itu bagi Sandi, warna biru juga melambangkan kaum pekerja. Sehingga dengan mengenakan pakaian baju kaos berwarna biru tersebut, Sandi ingin menunjukkan komitmennya untuk berpihak kepada kaum pekerja dan membuka lapangan pekerjaan yang seluas-luasnya (Syam, 2019).

Demikian halnya dengan model rambut Sandiaga Uno yang terkadang terbuka dan tertutup menggunakan peci hitam tidak seperti yang Prabowo lakukan. Akan tetapi, Sandi dapat menyesuaikankondisi dan tempat dimana harus dan tidak harus mengenakan peci ketika sedang melakukan kampanye politik.Jika dilihat, penggunaan peci di Indonesia adalah hal wajar bagi politisi maupun pejabat. Akan tetapi, apabila memakai peci akan dilabelkan sebagai sosok pribadi yang religius.
Selain dari pakaian, bahasa tubuh (body language) adalah salah satu aspek terpenting dari penampilan personal. Citra yang disampaikan oleh diri harus mendukung dan meningkatkan apa yang dikomunikasikan secara verbal. Jika imej visual sangat berbeda dari pesan yang diucapkan komunikator, maka khalayak lebih meyakini bentuk komunikasi non-verbal yang diberikan oleh komunikator. Menggunakan body language dalam strategi pencitraan politik merupakan salah satu cara untuk dapat meningkatkan penampilan diri.

Dengan simbol salam dua jari yang digunakan adalah memakai ibu jari dan telunjuk sehingga membentuk huruf $\mathrm{V}$ tersebut mengadung arti peace (damai) atau victory (kemenangan). Sedangkan Sandi mengatakan jari telunjuk mempunyai arti Tauhid dan jempol bermakna Universal (Catra Mulia, 2019).

Identiknya penggunaaan simbol tangan (hand gesture) ini digunakan ketika audiens sedang menyaksikan kampanye politik mereka. Kemudian pada saat meminta dukungan sehingga simbol jari ini menunjukkan dukungan masyarakat terhadap Prabowo-Sandi sebagai kandidat politik yang diidolakan. Selain itu, simbol tangan tersebut juga termasuk kategori dari objek yang berarti suatu tanda yang memiliki hubungan dengan penanda.

Jika dikaitkan dengan konsep pembawaan diri dalam kajian dramaturgi politik yang dijelaskan oleh Erving Goofman, konsep tentang penampilan ini dibutuhkan oleh seorang komunikator untuk dapat memproyeksikan gambaran tertentu tentang diri komunikator tersebut. Dalam konteks ini, Prabowo-Sandi melalui penampilan yang ditunjukkan di akun Instagram@indonesiaadilmakmur memproyeksikan pencitraan, sebagai definisi menyeluruh tentang situasi tersebut yang muncul. Maka, performa menjadi suatu hal yang tidak dapat dipandang mudah untuk menjelaskan sosok Prabowo-Sandi sebagai seorang komunikator politik (Littlejohn \& Foss, 2009: 130).
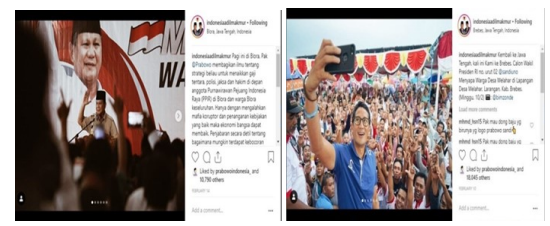

Gambar 4.1 Posting-an Penampilan Prabowo dan Sandi 
Personal branding Prabowo-Sandi Pada Sisi Personalitas

Pada kategori personalitas ini dapat diartikan sebagai suatu kepribadian kandidat. Di dalam kategori ini merupakan hubungan atau pidato percakapan PrabowoSandi dengan publik yang berkaitan dan tidak berkaitan dengan obrolan politik. Merujuk dari konsep Political Branding mengenai personalitas yang terdiri dari gaya bicara, tatanan bahasa, tingkah laku maupun bahasa tubuh yang digunakan kandidat. Kemudian bagaimana hubungan kandidat dengan masyarakat dan kemampuan persuasif serta intelektual kandidat dalam pidato kampanye politik mereka (Mitsikopoulou, 2008).

Ketika berkomunikasi yang berpengaruh bukan saja apa yang komunikator katakan, tapi juga keadaan dari komunikator itu sendiri. Dalam Rakhmat (2011: 251-253) Aristoteles menjelaskan bahwa seorang komunikator harus memiliki karakter yang disebut sebagai Ethous. Dimensi-dimensi Ethous ini menjelaskan pada tiga unsur, yaitu credibility (kepercayaan), source attractiveness (atraksi komunikator), dan source power (kekuasaan). Ketiga dimensi Ethous ini akan memberikan pengaruh sosial terhadap komunikan, seperti yang dijelaskan oleh Herbert C. Kelman (1975) yaitu internalisasi, identifikasi, dan ketundukan.

Hovland dan Weiss menyebut Ethous ini kredibelitas (credibelity) yang terdiri dari dua unsur yaitu expertise (keahlian) dan trustworthiness (dapat dipercaya). Baik Prabowo dan Sandi, membentuk kredibelitas adalah suatu yang penting dalam pembentukan citra politik. Kredibelitas menjadi bagian dari persuasi khalayak, yang tercapai karena karakteristik personal komunikator sehingga ketika komunikator menyampaikan pesannya maka akan dianggap kredibel. Pengaruh dari ketercapaiaan kredibelitas Prabowo dan Sandi ini adalah terbentuknya internalisasi pada persepsi khalayak atas citra diri Prabowo dan Sandi.

Hubungan kandidat dengan masyarakat merupakan bentuk komunikasi persuasif yang berarti seni dalam mempengaruhi audiens. K. Andeerson mendefinisikan sebagai perilaku komunikasi dengan tujuan untuk dapat mengubah keyakinan, sikap maupun perilaku individu maupun kelompok melalui penyampaian pesan. Maka, komunikasi persuasif bisa dilihat dari cara gaya bicara aktor politik (Mulyana, 2005: 115).

Dari sisi atraksi (source attractiveness), dapat dilihat pada sisi daya tarik fisik, kesamaan dan kemampuan yang dimiliki Prabowo dan Sandi dalam membangun ketertarikan khalayak. Selain pada penampilan yang gagah, Prabowo Subianto memiliki gaya bicara yang tegas, menggebu-gebu dan menggunakan intonasi tinggi di setiap kampanye politiknya. Hal itu merupakan label yang selama ini selalu melekat pada diri Prabowo. Gentri et al. (2015: 166), mengatakan Prabowo kerap dicitrakan sebagai pribadi yang tegas dan akan menjalankan ekonomi kerakyatan guna mengembalikan posisi kemajuan ekonomi Indonesia sebagai "Macan Asia". Mengingat latar belakangnya sebagai mantan prajurit dan Jendral di dunia militer, semakin memperkuat kepribadian maupun gaya bicaranya yang tegas dan keras (Lihat Gambar 4.2). Dengan demikian, orisinalitas itu kemudian membangun personalitas Prabowo sebagai pribadi yang keras dan tegas namun juga mempunyai sisi humoris. Sehingga nilai tersebut dapat dimaknai sebagai pemimpin yang keras dalam memperjuangkan aspirasi masyarakat Indonesia.

Personalitas yang berbeda juga ditunjukkan oleh Sandiaga Uno. Dari hasil interpretasi pemaknaaan tanda dari pisau bedah segitiga makna, peneliti menemukan ketika Sandi berbicara di depan audiens menunjukkan pribadi yang santun, tenang dan dikenal sebagai sosok milenial yang pintar. Selain itu, tutur bahasa yang digunakan adalah terstruktur atau disebut dengan istilah high contex sehingga memiliki retorika pemikiran yang menarik. Sebagai seorang komunikator, Sandi mempunyai kemampuan intelektual yang baik serta didukung penyampaiannya yang sopan mendukung pesan tersebut diterima oleh audiens. Dalam kajian komunikasi politik, salah satu indikator dalam menilai kredibilitas seorang komunikator politik adalah mempunyai kemampuan menyangkut pengetahuan, kepercayaan dan kejujuran (Fitriayasa, 2004: 2).

Hal ini sejalan dengan dimensi Ethous berikutnya yaitu kekuasaan (source power), baik Prabowo dan Sandiaga Uno memiliki kekuasaan keahlian (expert power) yang berasal dari pengetahuan dan pengalaman 
yang dimiliki masing-masing sebagai seorang pemimpin partai, mantan jenderal, dan pengusaha. Kekuasaan adalah kemampuan menimbulkan ketundukan, hal ini dibutuhkan bagi komunikator agar dapat memberikan ketundukan pada khalayaknya dan citra diri yang ingin dibentuk tersampaikan.

Oleh karena itu, Sandiaga Uno sering diundang menjadi motivator di acara-acara seminar tentang jiwa kewirausahaan. Pemilihan kata demi kata olehnya mengungkapkan penalaran yang logis atau masuk akal sehingga mampu menata pesan, ide, gagasan dengan baik. Kelebihan ini akan sangat berguna ketika menyampaikan ide atau gagasan baru untuk memajukan industri kreatif bidang perekonomian masyarakat. Mengingat latar belakang Sandiaga Uno yang merupakan salah satu pengusaha sukses yang ada di Indonesia.

Dalam istilah ilmu komunikasi menurut Ardial (2010: 73), ketika komunikasi politik sedang berlangsung, justru yang berpengaruh bukan hanya pesan politik yang disampaikan, melainkan siapa tokoh politik yang menyampaikan pesan politik itu. Dengan kata lain, personalitas tersebut merujuk pada diferensiasi Prabowo-Sandi yang membentuk branding sebagai sosok yang berbeda dengan politisi pada umumnya. Tetapi, di balik kepribadian yang bagus itu juga terdapat personalitas Prabowo-Sandi yang tidak efisien seperti pada gerakan ataupun bahasa tubuh yang diperagakannya.

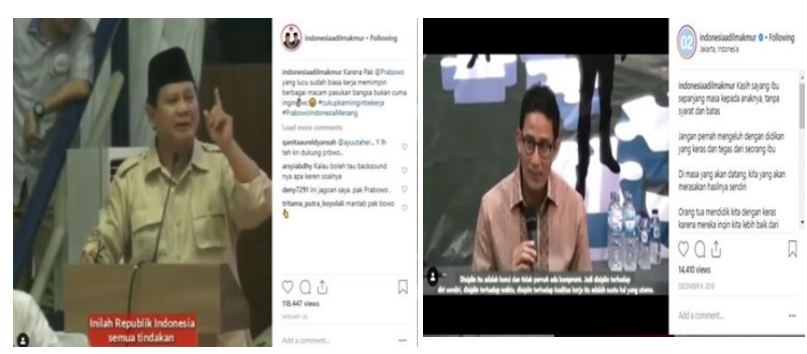

Gambar 4.2 Tangkapan Layar Video Prabowo dan Sandi saat Berbicara

Personal branding Prabowo-Sandi Pada Sisi Pesan Kunci Politik

Berdasarkan rujukan dari konsep Political Branding, pada kategori ini terbagi kedalam lima konsep indikator diantaranya berupa janji politik, gagasan poli- tik, aspirasi, harapan, nilai dan ideologi politik kandidat. Dalam hal ini, syarat yang perlu diperhatikan dalam menyusun pesan politik harus bersifat persuasif atau membujuk yang diantaranya, menentukan tema dan materi yang sesuai dengan kondisi dan situasi yang sedang terjadi di masyarakat. Kemudian syarat utamanya mampu membangkitkan semangat dan perhatian terhadap pesan-pesan yang disampaikan (Arifin, 2006: 72).

Dari beberapa posting-an yang diunggah di Instagram tersebut, yang menjadi pesan kunci politik Prabowo sesuai analisis menggunakan semiotika segitiga makna meyimpulkan bahwa aspek pesan politik menunjukkan bahwa Prabowo memiliki perasaan bangga membela rakyat Indonesia. Ideologi tersebut tak lepas dari latar belakangnya sebagai seorang patriot atau pejuang di masa jabatannya dalam dunia militer. Selain itu, gagasan politik Prabowo Subianto ingin menunjukkan bentuk kepeduliannya terhadap rakyat dan negara Indonesia

Menurut Haroen (2014: 13) menyebutkan bahwa identitas pribadi mengenai kualitas dan nilai yang dimiliki seseorang dapat menciptakan respon emosional orang lain. Identitas tersebut meliputi kemampuan, keunggulan dan reputasi yang memperlihatkan keunggulan dalam bidang tertentu. Sehingga janji yang menjadi nilai jual utama Prabowo adalah sikap optimistisnya sebagai pribadi yang akan menjamin bahwa Indonesia mampu mandiri dan tidak terlalu banyak bergantung pada negara luar.

Sedangkan yang menjadi aspek pesan kunci politik Sandiaga Uno adalah janjinya untuk berjuang mensejahterakan kaum ibu-ibu dan gagasan politiknya mengkritisi masalah aset negara yang dinilai salah arah. Berdasarkan hasil analisis semiotika segitiga makna peneliti menemukan bahwa Sandi mempunyai kedekatan yang amat besar diantara ibu-ibu dan kaum milenial. Itu terlihat karena Sandi mempunyai paras tampan dan menarik. Sehingga nilai utama yang ditawarkan Sandi pada masyarakat adalah menjamin ekonomi rakyat dan negara stabil bahkan lebih merakyat. Dengan demikian, arah segmentasi dan penancapan positioning pasangan Prabowo dan Sandi dianggap konsisten menggarap ekonomi kerakyatan bagi ka- 
langan masyarakat menengah kebawah. Melalui isu ini maka munculnya jargon-jargon seperti yang bertema ekonomi kerakyatan disetiap aktivitas kampanye politiknya.

Dalam psikologi pesan, seperti yang dikemukakan oleh Alan H. Monroe, terdapat lima langkah dalam menyusun pesan: attetion, need, satisfaction, visualization, dan action (Rakhmat, 2011: 292-293). Dalam konteks penelitian ini, pesan politik yang ditampilkan oleh tim pemenangan Prabowo-Sandi pada akun Instagram@indonesiaadilmakmur berupaya untuk membangun perhatian masyarakat Indonesia dengan mengambil tema-tema tentang ekonomi kerakyatan dan kesejahteraan yang dianggap sesuai dengan kebutuhan nyata dari masyarakat Indonesia. Agar muncul rasa kepuasaan khalayak, pesan-pesan tersebut disampaikan dengan menggambarkan hal-hal yang bisa dilakukan serta memberikan visualisasi visi dan misi di benak khalayak sehingga dapat meyakinkan khalayak untuk memilih bertindak.

\section{Citra Politik Prabowo-Sandi}

Pada dasarnya, pembentukan personal branding yang kuat merupakan landasan awal bagi lahirnya sebuah Political Branding. Berdasarkan analisis data penelitian branding Prabowo melalui sumber data Instagram, secara tidak langsung mempunyai peranan penting dalam penyampaian pesan selama masa kampanye politik. Adapun terciptanya personal branding tersebut merujuk pada diferensiasi sosok Prabowo yang berbeda dengan politisi lainnya. Hal itu dapat dilihat dari interpretasi dari konsep tanda teori segitiga makna (triangle meaning theory) yang diantaranya:

1) Beridentitas sebagai kaum elit

2) Berjiwa nasionalis

3) Berperilaku patriotisme

4) Optimistis

5) Religius

6) Berwatak tegas dan keras

7) Sesekali berprilaku humor

Sedangkan personal branding Sandiaga Uno yang dibentuk di Instagram juga mempunyai ciri khas dan branding tersendiri, maka interpretasi makna branding yang dimiliki Sandi juga mempunyai kemasan baru yang tidak berdasarkan perilaku meniru. Adapun personal branding Sandi diantaranya yaitu:

1) Memposisikan sebagai kaum milenial

2) Mempunyai kepribadian yang religius

3) Disukai oleh ibu-ibu

4) Berfisik sehat dan juga pintar.

Oleh karena itu, pentingnya membangun personal branding guna masyarakat mengetahui bahwa kandidat itu ada dan mempunyai daya tarik yang berkesan positif sehingga layak dipilih. Berdasarkan kajian teoritis, personal branding adalah tentang cara mengendalikan orang lain sebelum orang-orang tersebut melihat dan berhubungan langsung dengan Anda (Montoya \& Vandehey, 2008). Selain itu, personal branding merupakan identitas pribadi mengenai kualitas dan nilai yang dimiliki sehingga dapat menciptakan respon terhadap orang lain (Haroen, 2014: 13).

Jadi, personal branding merupakan suatu proses membentuk persepsi masyarakat terhadap aspek-aspek yang dimiliki seseorang, seperti kepribadian, kemampuan dan nilai yang kemudian stimulus-stimulus tersebut menimbulkan persepsi positif dari masyarakat (Susanto, 2009). Beranjak dari pemahaman tersebut, maka hasil interpretasi personal branding Prabowo dan Sandiaga Uno jika digabungkan menjadi suatu Political Branding.

\section{KESIMPULAN}

Dari pembahasan yang telah dijabarkan, maka dapat ditarik kesimpulan bahwa pembentukan Political Branding Prabowo-Sandi dibentuk melalui tiga jenis pendekatan konsep seperti penampilan (appereance), personalitas (personalities) dan pesan kunci politik (political key message). Bahkan, lebih spesifik yaitu adanya pembangunan hubungan dengan audiens. Sebagai sosok yang berkepribadian berbeda dengan politisi lain, pada umumnya seperti memiliki sikap orisinalitas sebagai calon pemimpin dan mempunyai ideologi dan intelektual yang menarik.

Sehingga dari penjabaran diatas, Political Brand- 
ing Prabowo tergambar sebagai sosok pribadi yang tegas, keras, pejuang, optimis dan humoris. Sedangkan Sandi memiliki pribadi yang religius, sopan, tenang, berintegritas, pintar, dan dekat dengan masyarakat.

Secara keseluruhan Political Branding Prabowo -Sandi adalah lebih banyak ditampilkan sisi baiknya. Walaupun juga terdapat beberapa branding yang tidak baik seperti pada gerakan-gerakan maupun komunikasi non-verbal yang mengandung pemaknaan yang bersifat negatif. Pada sisi lain, pasangan kandidat ini menampilkan citra yang kuat guna menancapkan positioning dibenak hati masyarakat.

Oleh karena itu, branding Prabowo-Sandi tersebut mengarah sebagai suatu ciri khas ataupun karakter yang belum ada karena mempunyai diferensiasi unik dan menarik daripada ciri politisi Indonesia yang sudah ada sebelumnya. Hal itu dapat dilihat dari penampilan, kepribadian maupun pesan-pesan politik yang berbeda sehingga mempunyai identitas sendiri untuk mudah dikenali oleh masyarakat.

Sebagai rekomendasi untuk penelitian selanjutnya, kajian pada sisi khalayak sebagai komunikan diperlukan untuk melihat pada konteks penerimaan yang terbentuk pada khalayak sebagai objek dari bentukan citra politik komunikator. Kajian teks hanya menggambarkan bentukan citra secara konseptual dari sisi subjek citra, sedangkan khalayak dapat memberikan gambaran objektif tentang keefektifan dari strategi branding yang dilakukan oleh komunikator dalam sudut pandang khalayak. Tercapai atau tidaknya strategi pencitraan politik seorang komunikator dapat diukur dari seberapa relevannya kesamaan makna pada citra yang terbentuk dalam persepsi khalayak.

\section{DAFTAR PUSTAKA}

Arifin, Anwar. (2006). Ilmu Komunikasi: Sebuah Pengantar Ringkas. Jakarta: Raja Grafindo Persada.

Mulyana, Dedi. (2005). Ilmu Komunikasi Suatu Pengantar. Bandung: Remaja Rosdakarya

Dubrin Andrew J., (2005). Leadership (Terjemahan), Edisi Kedua, Prenada Media, Jakarta.

Gelder, S.V. (2003).Global Brand Strategy: Unlocking Brand Potential Across Countries. London: Kogan
Page.

.(2007). Human Relations, Interpersonal Job-Oriented Skills. 9 Edition, New Jersey: Pearson Prentice Hall.

Krippendorff, K. (2004). Content analysis: an introduction to its methodology. Thousand Oaks, California: SAGE Publications.

Littlejohn, S.W., Foss K.A. (2009). Teori Komunikasi:

Theories of Human Communication. Jakarta: Salemba Humanika.

Montoya, Peter, \& Vandehey, Tim. (2008). The Brand Called You: Make Your Business Stand Out in a Crowded marketplace (paperback). United States of America: McGraw-Hill.

Rakhmat, Jalaluddin. (2011). Psikologi Komunikasi. Bandung: Remaja Rosdakarya

Sobur, Alex. (2001). Analisis Teks Media: Suatu Pengantar Untuk Analisis Wacana, Analisis Semiotik, dan Analisis Framing. Bandung: Remaja Rosda Karya.

Sugiyono. (2008). Metode Penelitian Kuantitatif, Kualitatif, dan R\&D. Bandung: Alfabeta.

Suharsimi, Arikunto. (2006). Prosedur Penelitian: Suatu Pendekatan Praktek. Edisi Revisi. Jakarta: PT Rineka Cipta

Sumbo, Tinarbuko. (2009). Iklan Politik dalam Realitas Media. Yogyakarta: Jalasutra.

Vera, Nawiroh. (2015). Semiotika dalam Riset Komunikasi. Bogor: Ghalia Indonesia.

Abidin, Sholihul. (2019). Political Branding Ridwan Kamil Pada Masa KampanyePilgub Jawa Barat 2018 Melalui Twitter. Jurnal Commed: Komunikasi dan Media.Vol.4(1). 33-48.

Amalo, G.F.P. (2015). Prabowo Subianto dan Soekarnoeisme. Jurnal Interaksi.Vol. 4 (2). 165-174.

Downer, L. (2013). Political Branding in Australia: a Conceptual Model. 63rdPolitical Studies Association Annual International Conference. Cardiff: Political Studies Association.

Fitri, Ainal. (2015). Dramaturgi: Pencitraan Prabowo Subianto di Media Sosial Twitter Menjelang Pemili- 
han Presiden 2014. Jurnal Interaksi.Vol.4(1). 101-108.

Fitriyasa. Efektivitas Komunikasi Politik Erma Ranik (anggota DPD Asal Kalimantan Barat)

Dengan Masyarakat Perbatasan Desa Sebunga Kecamatan SajuganBesar. Jurnal Politika.Vol.5(2). 